\title{
Effect of Fistula in Ano Surgery on Anorectal Manometric Study
}

\author{
USAMA S. MOHAMED, M.D.; KHALIL EL-GENDY M.Sc. and AHMED FARAG, M.D. \\ The Department of General Surgery, Faculty of Medicine, Cairo University
}

\begin{abstract}
Background: Surgical treatment of anal fistula is associated with a significant risk of impaired continence. Anorectal manometry is the most widely available tool for investigating anorectal function.

Patients and Methods: Twenty patients of age ranging from twenty to sixty years old underwent treatment of anal fistula. They did anorectal manometry before and two months after management.

Results: Significant decrease noted in the resting and squeezes pressure and maximal tolerable volume in the rectum.

Conclusion: Anorectal manometry is a valuable tool in detecting the effect of anal fistula surgery on anorectal function even in subclinical conditions that may be helpful in opening the way for studies predicting high risk patient after anal fistula surgery to start treatment before reaching the clinical condition.
\end{abstract}

Key Words: FISTULA - Ano surgery - Anorectal manometric.

\section{Introduction}

FISTULA-IN-ANO surgery has been performed for decades however, definitive management is still a challenge for surgeons because risks of recurrence and incontinence are still not uncommon. This made the surgeons move to less aggressive techniques such as fistula glue and collagen plug [1-5]. Recurrence rate after these procedures is still not satisfactory. Surgeons are still treating simple low anal fistulas with fistulotomy as this provides the best recurrence free approach. However we are concerned that this approach may lead to quiescent sphincter damage that may potentially manifest in the future and cause incontinence. Using anal retractor alone can be a risk factor for incontinence in those patients $[6,7]$. Few studies have assessed the sphincter function using Anorectal manometry after low fistula-in-ano surgery. We aim at evaluating the effect of low fistula-in-ano

Correspondence to: Dr. Usama S. Mohamed, The Department of General Surgery, Faculty of Medicine, Cairo University surgery on the sphincter function in term of pressures, sensations and reflexes.

\section{Patients and Methods}

We prospectively conducted a study on 20 patients ( 11 men and 9 women) who underwent surgery for low trans-sphincteric fistula-in-ano at Cairo University Hospital (Egypt) between 2010 and 2011. The study was approved by the Ethics Committee of the hospital, and the patients signed a written informed consent. Fistulas were classified According to Park's classification [8] and transsphincteric fistulas with track involving less than third of the external sphincter were included. Patients with complex or recurrent fistulas, fistulas associated with inflammatory bowel disease, irradiation, trauma or neoplasia were excluded from the study. Moreover, patients with pschycological problems were also excluded. Pre-operative assessment included history and physical examination with a focus on risk factors for incontinence. Colonoscopy was performed if required.

A special standardized data collection sheet designed for the purpose of the study was used.

Anorectal manometry was performed by an independent observer using a water perfusion system equipped with a filled 8-lumen catheter. The pressure was recorded by pressure transducers within each infusion line and were connected to a computer system. Anorectal manometry was conducted on the day before surgery. Antithrombotic prophylaxis and antibiotic prophylaxis were administered.

\section{Surgical procedure:}

Fistula surgery was performed by consultant surgeons in Cairo University Hospital Coloproctology Unit. Patient was placed in Lloyd Davies Position, and the fistula track was verified using Hydrogen Peroxide injected through the external 
opening. Fistula was laid open using electro-cautery and fistula track was curetted.

\section{Post-operative care:}

Enteral nutrition was provided and patient was discharged on the same day. Oral antibiotics were given for 5 days. Patients were followed-up in outpatient clinic weekly until the wound completely healed.

\section{Follow-up:}

Anorectal manometry was conducted 3 months after surgery. Continence was assessed 3 months after treatment according the wexner continence grading scale [9]. Results was compared with the pre-operative findings.

\section{Statistics:}

Data was expressed as the mean \pm standard deviation. The student $t$-test was used to compere preoperative with postoperative results. A $p<0.05$ was considered statistically significant.

\section{Results}

Patient characteristics of the patients are shown on Table (1). The mean age was $35.5 .55 \%$ of the patients were male and $45 \%$ were female. All patients had a simple transsphincteric fistula track involving less than third of the external sphincter. All patients were treated with fistulotomy.

Anal abscess has been previously drained in $60 \%$ of patients. The duration of symptoms in the current episode was 6 months. The mean postoperative stay in the hospital was 0.4 days with 12 patients discharged in the same day. Readmission episodes were zero. Post-operative complications were urine retention in 1 patient. Mean healing time was 5.6 weeks. Zero patients were lost during the follow-up.

The mean wexner score didn't change significantly after surgery. According to the Anorectal manometry significant decrease in resting and sueeze pressure occurred. Significant decrease in maximum tolerable volume was also noted.

Table (1): Patients' characteristics.

\begin{tabular}{ll}
\hline Age & 35.5 (Range: $25-55)$ \\
Sex (M/F) & $11 / 9$ \\
Recurrent fistula & 0 \\
Continence (continent/incontinent) & $20 / 0$ \\
Previous abscess drainage & $12(60 \%)$ \\
Duration of symptoms (months) & 6 \\
Hospital stay (Days) & 0.4 \\
Readmission & 0 \\
Healing time (weeks) & 5.6 (Range: $4-8)$ \\
\hline
\end{tabular}

Results are summarized in Table (2).

Table (2): Continence before and after surgery using Wexner score.

\begin{tabular}{rlcr}
\hline \multicolumn{1}{c}{ Type } & Mean & SD & $t$-test \\
\hline Wexner Score Pre & 0.75 & 0.72 & 0.096 \\
Post & 1 & 0.73 & \\
Difference & $0.25(33 \%)$ & 0.03 & \\
\hline
\end{tabular}

Table (3): Anorectal manometric findings before and after surgery.

\begin{tabular}{|c|c|c|c|c|}
\hline & Type & Mean & SD & $t$-test \\
\hline \multirow{3}{*}{$\begin{array}{l}\text { Resting } \\
\text { maximal Anal } \\
\text { pressure }\end{array}$} & Pre & 115.6 & 17.899 & \multirow[t]{3}{*}{0.0025} \\
\hline & Post & 94.1 & 23.617 & \\
\hline & Difference & $21.5(19 \%)$ & 24.237 & \\
\hline \multirow{3}{*}{$\begin{array}{l}\text { Resting } \\
\text { average Anal } \\
\text { pressure }\end{array}$} & Pre & 45.35 & 7.969 & \multirow[t]{3}{*}{0.0738} \\
\hline & Post & 38.7 & 14.075 & \\
\hline & Difference & $5.85(13 \%)$ & 11.873 & \\
\hline \multirow{3}{*}{$\begin{array}{l}\text { Average } \\
\text { squeeze } \\
\text { maximal Anal } \\
\text { pressure }\end{array}$} & Pre & 210.85 & 41.716 & \multirow[t]{3}{*}{0.0040} \\
\hline & Post & 175.85 & 29.382 & \\
\hline & Difference & $39.85(19 \%)$ & 49.877 & \\
\hline \multirow{3}{*}{$\begin{array}{l}\text { Average } \\
\text { squeeze } \\
\text { average Anal } \\
\text { pressure }\end{array}$} & Pre & 88 & 22.583 & \multirow[t]{3}{*}{0.0117} \\
\hline & Post & 72.05 & 14.688 & \\
\hline & Difference & $16.3(19 \%)$ & 24.201 & \\
\hline \multirow{3}{*}{$\begin{array}{l}\text { Squeeze } \\
\text { Amplitude } \\
\text { relative to } \\
\text { zero }\end{array}$} & Pre & 219.55 & 64.899 & \multirow[t]{3}{*}{0.0736} \\
\hline & Post & 185.15 & 52.716 & \\
\hline & Difference & 34.4 & 88.099 & \\
\hline \multirow{3}{*}{$\begin{array}{l}\text { Squeeze } \\
\text { Pressure } \\
\text { increase }\end{array}$} & Pre & 122.15 & 55.606 & \multirow[t]{3}{*}{0.5602} \\
\hline & Post & 112.7 & 45.592 & \\
\hline & Difference & 9.45 & 66.877 & \\
\hline \multirow{3}{*}{$\begin{array}{l}\text { Endurance } \\
\text { squeeze time } \\
\text { (s) }\end{array}$} & Pre & 29.95 & 0.224 & \multirow[t]{3}{*}{0.0932} \\
\hline & Post & 29.5 & 1.147 & \\
\hline & Difference & 0.45 & 0.945 & \\
\hline \multirow{3}{*}{$\begin{array}{l}\text { Endurance } \\
\text { squeeze area } \\
\text { under the } \\
\text { curve }\end{array}$} & Pre & 2292.05 & $1,185.748$ & \multirow[t]{3}{*}{0.0528} \\
\hline & Post & 1708.85 & 543.966 & \\
\hline & Difference & 590.25 & $1,008.021$ & \\
\hline \multirow{3}{*}{$\begin{array}{l}\text { Average } \\
\text { relative } \\
\text { cough } \\
\text { pressure }\end{array}$} & Pre & 82.4 & 42.521 & \multirow[t]{3}{*}{0.8567} \\
\hline & Post & 84.5 & 29.303 & \\
\hline & Difference & 2.1 & 62.292 & \\
\hline \multirow{3}{*}{$\begin{array}{l}\text { 1 st sensation } \\
\quad(\mathrm{ml})\end{array}$} & Pre & 49 & 27.319 & \multirow[t]{3}{*}{0.3169} \\
\hline & Post & 42 & 14.364 & \\
\hline & Difference & 7 & 36.577 & \\
\hline \multirow[t]{3}{*}{ First urge (ml) } & Pre & 82 & 26.278 & \multirow[t]{3}{*}{0.1094} \\
\hline & Post & 69 & 23.819 & \\
\hline & Difference & 13 & 39.617 & \\
\hline \multirow{3}{*}{$\begin{array}{l}\text { Modest urge } \\
\quad(\mathrm{ml})\end{array}$} & Pre & 128.5 & 45.569 & \multirow[t]{3}{*}{0.0633} \\
\hline & Post & 103.5 & 36.602 & \\
\hline & Difference & 26.5 & 30.655 & \\
\hline
\end{tabular}


Table (3): Cont.

\begin{tabular}{cllcl}
\hline & Type & Mean & SD & $t$-test \\
\hline Maximum tolerable & Pre & 166 & 45.584 & 0.0041 \\
volume & Post & 131 & 23.373 & \\
& Difference & $35(21 \%)$ & 39.537 & \\
Rectal Compliance & Pre & 34.075 & 31.465 & 0.1633 \\
$(\mathrm{ml} / \mathrm{mmHg})$ & Post & 23.19 & 13.509 & \\
& Difference & -10.885 & 34.426 & \\
\hline
\end{tabular}

\section{Discussion}

Concerns about sphincter division in anal fistula surgery goes as far as 1985 when Belliveau et al., reported decrease in resting anal pressure after fistulotomy for intersphincteric fistula [10]

In 2003, Chang et al., reported decrease in continence and resting anal pressure after laying open intersphincteric fistulas with those who has low pre-operative resting tone has higher risk. Both suggested conservative surgery should be considered in selected cases of intersphincteric fistulas [11]

Our current study found significant reduction in anal pressures after fistulotomy which agrees with the above studies. We also found a significant reduction in rectal compliance which may be due to changes in rectal sensations.

Laying fistula open is a simple and effective therapy for low anal fistulas especially for patients with normal sphincter function. The current trend is to look at the remaining bulk of the sphincter rather than the part cut during the operation. Our study highlighted that we underestimate the sphincter damage caused by fistulotomy. Cutting any part of the sphincter will definitely reduce the sphincter muscle bulk and even if that doesn't lead to clinical incontinence in the short post-operative period it can be an added factor to the future damage to the sphincter by direct trauma (like caesarean section or surgery for a fistula in the future) or even aging process. Patients should be counselled during the pre-operative period about the small possibility of having clinically evident incontinence in the future. Also there may be a window for pre-emptive treatment of subclinical incontinence in those patients (by repairing the sphincter in low fistula surgery) or postoperative physiotherapy and long-term follow up to make sure that sphincter power has returned to normal parameters.

Change in rectal sensation is an unexpected finding but this may be due to surgical alteration of the anal canal sensation via direct injury to the mucosa or by using diathermy which may lead thermal injury to the adjacent tissues. We found significant decrease in maximum tolerable volume which has led to a reduction in rectal compliance by $31 \%$ but this change was not statistically significant. Obviously change in rectal compliance has a strong role in impairing continence. Pescatori et al., in 2004 reported changes in rectal sensation in incontinent patients after fistula surgery and concluded that rectal sensations may play a role in incontinence patients [12].

The small number of the patients included in this study is one of its limitations. Also follow-up is of short term and we recommend longer term follow-up studies to find out if Anorectal manometric changes are temporary or permanent. Also changes in the maximum tolerable rectal volume may be a result of post-operative discomfort that may disappear over time.

We strongly recommend that sphincter saving procedures should be considered as an alternative to fistulotomy in those patients who may develop risk factors in the future.

\section{Conclusion:}

There is enough objective evidence that fistulotomy reduces sphincter function even in low anal fistulas.

Subclinical incontinence may lead to clinically evidence incontinence when other factors start playing its effect later on.

Patient should be informed about future possible risk of incontinence and should be given the opportunity to choose a sphincter saving procedure if possible.

Pre-emptive correction of incontinence may be a good option those patients who undergo fistulotomy and may become at risk in the future.

\section{References}

1- MARALCAN G., et al.: "The use of fibrin glue in the treatment of fistula-in-ano: A prospective study". Surg. Today, 36 (2): 166-70, 2006.

2- KOCKERLING F., et al.: "Treatment of Fistula-In-Ano with Fistula Plug-a Review Under Special Consideration of the Technique". Front Surg., 2: 55, 2015.

3- SABA R.B., et al.: "Treating anal fistula with the anal fistula plug: Case series report of 12 patients". Electron Physician, 8 (4): 2304-7, 2016.

4- ROMERO G.T., et al.: "Treatment of fistula-in-ano with cyanoacrylate glue with and without prior seton placement in rats". Acta. Cir. Bras., 31 (6): 377-81, 2016. 
5- KOUCHI K., et al.: "Efficacy of an anal fistula plug for fistulas-in-Ano in children". J. Pediatr. Surg., 52 (8): 1280-2, 2017

6- MARALCAN G., et al.: "Long-term results in the treatment of fistula-in-ano with fibrin glue: A prospective study". J. Korean Surg. Soc., 81 (3): 169-75, 2011.

7- CESTARO G., et al.: "Treatment of fistula in ano with fibrin glue: Preliminary results from a prospective study". Minerva Chir., 69 (4): 225-8, 2014.

8- PARKS A.G., et al.: "A classification of fistula-in-ano". Br. J. Surg., 63 (1): 1-12, 1976.

9- JORGE J.M. and S.D. WEXNER: "Etiology and manage- ment of fecal incontinence." Dis. Colon. Rectum., 36 (1): 77-97, 1993.

10- BELLIVEAU P., et al. : "Symposium on outpatient anorectal procedures. Panel discussion". Can. J. Surg., 28 (3): 239-40, 1985.

11- CHANG S.C. and J.K. LIN: "Change in anal continence after surgery for intersphincteral anal fistula: A functional and manometric study". Int. J. Colorectal Dis., 18 (2): 111-5, 2003.

12- PESCATORI M., et al.: "Can anal manometry predict anal incontinence after fistulectomy in males?" Colorectal Dis., 6 (2): 97-102, 2004.

\title{
تأثير علاج الناسور الشرجى معئى على مقياس ضغوج الناسور الشرج
}

\author{
مقدمة: العلاج الجراحي للناسود الشرجى يكن مصاحباً بتأثير ملحفظ على تمكم فى البراز. مقياس ضغوط

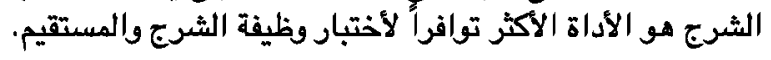 \\ المرضى وطرق الدراسة: عشرن مريضاً يترواح أعمارهم ما بين العشرين والستين قاموا بعلاج الناسود الشرجى

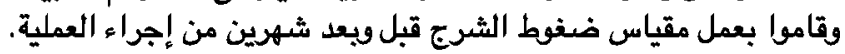 \\ النتائج: انخفاض ملحوظ فى ضغط عضلة الشرج أثناء الارتخاء وأثناء قبض العضلة اراديا وانخفاض فى أقصى

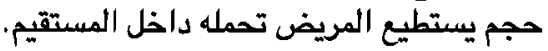

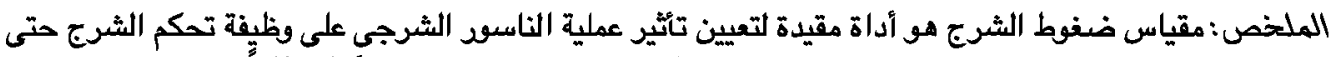

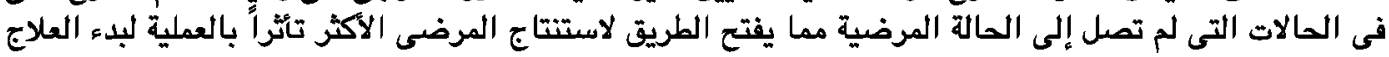

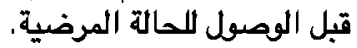

